\title{
THE CORRELATION BETWEEN STUDENTS' VOCABULARY MASTERY AND THEIR READING COMPREHENSION AT THE SEVENTH GRADE STUDENTS' OF MTs DAARUL IHSAN
}

\author{
Dasep Samsul Bahri ${ }^{1}$ \\ ${ }^{1}$ IKIP SILIWANGI \\ 1.Samsuldasep@gmail.com
}

\begin{abstract}
The study investigated the correlation between students' vocabulary mastery and their reading comprehension. Data were collected from 32 seventh grade students. The test item of vocabulary mastery and reading comprehension were given to the students to measure their level of vocabulary mastery and reading comprehension. The results were compared to find out the correlation between those variables. Showed that there was strong correlation between students' vocabulary mastery and their reading comprehension. The current study concluded that students' experiences' experiences and reading strategies help the students to understand text but vocabulary was more contributive in helping the students to comprehend the texts.
\end{abstract}

Keywords: correlation, vocabulary mastery, reading comprehension ability.

\section{INTRODUCTION}

Reading is one of the important language skills. By reading, people may get a lot of information. The more he/she reads, the more information he/she will get. Reading makes someone smarter and creative. According to Laddoo (2007) reading forces the reader's brain cells to work on a regular basis as this will keep the reader sharper and smarter. Even though some information can be obtained without reading, for example by listening teacher, seminar, radio, television etc, but reading someone may get wider information than listening. For example, someone who reads a newspaper will get more information than someone who watches news on television. Reader can read the text again when he/she forgets or tries to get detail information, while listener cannot. This is supported by Willis (2008) who states that by reading, someone can find the information he/she needs with specific information.

From the description above, the writer attempts to find out the correlation between students' vocabulary mastery and their reading comprehension and to find out how high the correlation between vocabulary mastery and reading comprehension is. The subject of this research are the students of seventh grade of MTs DAARUL IHSAN. The results of this study are expected to enrich the literature on research regarding to the relation of students' vocabulary mastery and their reading comprehension.

According to nation and Newton (1997) vocabulary is knowledge of words and word meanings. Actually vocabulary is more complex, vocabulary mastery is not only knowing the words and its meaning, but also knowing about how the words sound and how the words are used in context. I is according to Miller and Gildea (1987) who state that knowing a word by sight and sound and knowing a word by sight and knowing its dictionary definition are not same as knowing how to use the word correctly and understanding it heard or seed in various contexts.

Building up a useful vocabulary is central to the learning of a foreign language at primary level (Cameron, 2001). Someone who has a lot of vocabulary of foreign language, she/he could learn language easily. Since vocabulary is all about words, and good mastery of 
vocabulary helps someone understand language. When a learner intens to learn foreign language, he/she has learn the vocabulary of the foreign language first.

Wallace (1982) mentions two importances of vocabulary:

a. Language exist in two forms, spoken and written, both of them need vocabulary to develop the existence itself.

b. Vocabulary is one of the important of foue language skills. Therefore, vocabulary is very needed for production in learning English as a foreign language rather than only needed for recognition it.

Furthermore, Lehr and Osborn (2001) explain two kinds of vocabulary description as follow:

First, words come in two forms, oral and print.

a. Oral vocabulary includes the words that are recognized and used in listening and speaking.

b. Print vocabulary includes the words that are recognized and used in reading and writing. Second, word knowledge is composed of two forms, receptive and productive.

a. Receptive vocabulary includes words that are recognized when we hear or see them. It is the ability to comprehend passive vocabulary which is used in reading and listening context.

b. Productive vocabulary includes words that are recognized whe we speak or write. It is an active ability which is used in speaking and writing.

Furthermore, knowing and understanding words mean knowing their "form" ( how they sounds, how they spelt, grammatical change that could be made to them), their "meaning" ( their conceptual context, and how they relate to other words and particular types of language use (Cameron, 2001).

However, according to Klingner, Vaughn and Boardman (2007) reading is a processs of constructing meaning can be achieved through dynamic instruction among the following aspects: the reader's prior knowledge, the information suggested by text, and the context of the reading situation.

\section{Reading Comprehension}

According to Ruddell (1994) as cited in Apriani (2011) comprehension is a process in which a reader construcs meaning while, or after, interacting with text through the combination of prior knowledge and previous experience, information in text, reader takes in relationship to the text, and immediate, remember, or anticipated social interactions and communication.

Those definitions above suggest that comprehension is achieved when reader successfully extract yhe useful knowledge from a text and constructs it into a new understandings of their own. Accourding to Day and Park (2005) also propose several types of comprehension, as follows :

1. Literal comprehension

2. Inferential comprehension

3. Reorganization

4. Predictive comprehension

5. Evaluative comprehension

6. Appreciative or personal comprehension

7. Reading Strategies

When the reader's find unknown words in the text, they should have some strategies to comprehend those words. According to Caverly and Peterson (1996) whos state that to understand the text the reader's needs to find the key words of the text. This will allow the readers to understand the meaning of the unknown words. While according to Mcentire(2003, p.29) when the reader's find unknown words, the reader's do not need to look up every words in dictionary, the readers can often guess the meaning of new words through context. 


\section{Reading Strategies}

When the reader's find unknown words in the text, they should have some strategies to comprehend those words. According to Caverly and Peterson (1996) whos state that to understand the text the reader's needs to find the key words of the text. This will allow the readers to understand the meaning of the unknown words. While according to Mcentire(2003, p.29) when the reader's find unknown words, the reader's do not need to look up every words in dictionary, the readers can often guess the meaning of new words through context.

Being a strategies requires a set of strategies that work well in combination. Grabe and Stoller (2002) explain that there are three models of reading :

1. Top-down model

2. Bottom-up model

3. Integrated model

Furthermore, Adler (1972) explains that there are some techniques which can be used to make reading faster and efficient. The technique are :

1. Skimming

2. Scanning

Those strategies are very helpful in reading. However, the effectiveness of reading depends on the readers ability to use those strategies. Skimming is used when readers need a general idea of a books subject matter. On the other side, scanning is used when readers need to gather specific information.

\section{METHOD}

\section{Research Design}

In this present research, quantitative approach with correlation method is employed. Quantitative research is used since this research focuses on analyzing the data through systematic process by using certain computation. Creswell (2012: 12) describe on his book: experimental design, correlation design, and survey design. To conduct this research the writer takes correlational designs where the design are divided into two design: explanatory design and prediction design. The writer select explanatory design to this research.

\section{Research Method}

Quantitative research design can be classified into four method: 1) experimental method, 2) correlation method, 3) causal-comparative method and survey method (creswell,2012:Fraenkel, Wallen, Hyun, 2012, cited is Kaswan and Suprijadi, 2013:13). According to the research design used and the title of this research, the writer used correlational method, because the objective is to study and find the relationship between two variables that are correlation between students' vocabulary mastery and reading comprehension.

\section{Population and Sample}

The writer used cluster sampling to determine the sample for this research. The writer took one class that is the seventh grade students of MTs DAARUL IHSAN. They are 32 students as the sample of this research.

\section{Instruments}

In this study the writer need to use an instrument to help in collecting the data research, Tavakoli (in Kaswan and Suprijadi,2013:107) said that "instrument is any device which is used to collect the data". Instruments can be presented in written, audio or visual format. The instrument which was used in this study was divide into two kinds. The first was vocabulary mastery test and second was reading comprehension test that use multiple-choice type. The test consisted of 20 item test with five alternatives. The alternatives included one correct answer and four wrong answers.

\section{Data Collection Technique and Analysis}




\section{A. Data collection technique}

The procedure of data collecting used in this research was :

1. Testing

The writer used two kinds of test to investigate the correlation between vocabulary mastery and reading comprehension, so the writer used test method. The test consisted of 10 items and divided into two parts: the first was vocabulary mastery test which consisted 10 items test and the second was reading comprehension test which also consisted 10 items tests.

\section{B. Data Analysis}

The purpose of this research was to measure the correlation between student's vocabulary mastery and their reading comprehension. The data of the study were analyzed by using statistical analysis. Statistic is the science of collecting, organizing, summarizing, and analyzing information to draw conclusions or answer questions (Sullivan, 2008:3). To measure the correlation both the two variables, the writer use Spearman formula. According to Pallant (2007:1), "SPSS is an enormously powerful data analysis package that can handle very complex statistical procedures". It means, SPSS is a powerful data analysis package that capable of handling large amount of the data and it can perform all data of the analysis covered in the text.

\section{Normality test}

Normality test was conducted to determine whether the research data obtained was normality disturbed or not, measures to the rest normality by using one samplekolmogorovsmirnov test in SPSS.

\section{The Spearman rho correlation}

The writer used the Spearman rho correlation, because the data is not normally disturbed. According to Hinton et al (2004:300), "when data is not normally disturbed, or when other assumptions of the person correlation are vioted. On these occasions we use the Spearman correlation coefficient, which is the nonparametric equivalent of the Pearson correlation".

\section{RESULTS AND DISCUSSION}

\section{Results}

As it has been mentioned in the previous chapter, the writer conducted field research. Having finished doing research on correlation study between students vocabulary mastery and reading comprehension done by eleventh grade students of MTs Daarul Ihsan, the writer collected the data of this research from the scores available. It was the result obtained by the group of the students who had completed the subject of vocabulary and reading.

The writer took scores of 32 students randomly and analysed those scores in order to find out whether there is any correlation between students vocabulary mastery and their reading comprehension by using the spearman $r_{s}$ formulas. In this chapter, the writer gave the report concerning the data description and compares the achievement of those two scores.

Based on the test given, the total score of the eleventh grade students of MTs Daarul Ihsan in terms of vocabulary mastery was 2110 . The result could be seen in Table 4.1 as follows

Table 1 The scores of Vocabulary Mastery (X) of the eleventh grade students of MTs Daarul Ihsan

\begin{tabular}{|c|c|c|}
\hline No & Names & X \\
\hline 1 & Student 1 & 70 \\
\hline 2 & Student 2 & 65 \\
\hline
\end{tabular}




\begin{tabular}{|c|c|c|}
\hline 3 & Student 3 & 60 \\
\hline 4 & Student 4 & 55 \\
\hline 5 & Student 5 & 45 \\
\hline 6 & Student 6 & 70 \\
\hline 7 & Student 7 & 75 \\
\hline 8 & Student 8 & 60 \\
\hline 9 & Student 9 & 65 \\
\hline 10 & Student 10 & 60 \\
\hline 11 & Student 11 & 80 \\
\hline 12 & Student 12 & 65 \\
\hline 13 & Student 13 & 75 \\
\hline 14 & Student 14 & 90 \\
\hline 15 & Student 15 & 65 \\
\hline 16 & Student 16 & 50 \\
\hline 17 & Student 17 & 75 \\
\hline 18 & Student 18 & 75 \\
\hline 19 & Student 19 & 75 \\
\hline 20 & Student 20 & 60 \\
\hline 21 & Student 21 & 70 \\
\hline 22 & Student 22 & 60 \\
\hline 23 & Student 23 & 75 \\
\hline 24 & Student 24 & 55 \\
\hline 25 & Student 25 & 70 \\
\hline 26 & Student 26 & 50 \\
\hline 27 & Student 27 & 65 \\
\hline 28 & Student 28 & 60 \\
\hline 29 & Student 29 & 60 \\
\hline 30 & Student 30 & 70 \\
\hline 31 & Student 31 & 80 \\
\hline 32 & Student 32 & 60 \\
\hline \multicolumn{2}{|c|}{ Total $\left(\sum\right)$} & 2110 \\
\hline
\end{tabular}

Table 2 The scores of Reading Comprehension (Y) of the eleventh grade students of MTs Daarul Ihsan

\begin{tabular}{|c|c|c|}
\hline No & Names & Y \\
\hline 1 & Student 1 & 65 \\
\hline 2 & Student 2 & 60 \\
\hline 3 & Student 3 & 60 \\
\hline 4 & Student 4 & 60 \\
\hline 5 & Student 5 & 50 \\
\hline 6 & Student 6 & 60 \\
\hline 7 & Student 7 & 70 \\
\hline 8 & Student 8 & 60 \\
\hline 9 & Student 9 10 & 60 \\
\hline 10 & Student 10 11 & 60 \\
\hline 11 & Student 11 & 85 \\
\hline 12 & Student 12 & 60 \\
\hline 13 & Student 13 & 65 \\
\hline
\end{tabular}




\begin{tabular}{|c|c|c|}
\hline 14 & Student 14 & 85 \\
\hline 15 & Student 15 & 65 \\
\hline 16 & Student 16 & 40 \\
\hline 17 & Student 17 & 75 \\
\hline 18 & Student 18 & 70 \\
\hline 19 & Student 19 & 80 \\
\hline 20 & Student 20 & 60 \\
\hline 21 & Student 21 & 60 \\
\hline 22 & Student 22 & 60 \\
\hline 23 & Student 23 & 60 \\
\hline 24 & Student 24 & 45 \\
\hline 25 & Student 25 & 55 \\
\hline 26 & Student 26 & 45 \\
\hline 27 & Student 27 & 60 \\
\hline 28 & Student 28 & 65 \\
\hline 29 & Student 29 & 55 \\
\hline 30 & Student 30 & 60 \\
\hline 31 & Student 31 & 60 \\
\hline 32 & Student 32 & 60 \\
\hline \multicolumn{2}{|c|}{ Total $\left(\sum\right)$} & 1975 \\
\hline
\end{tabular}

\section{Data Analysis}

\section{a. Normality Test}

Before calculating the data, the writer checked the normality of the data. The wiriter used SPSS program to find out whether the data normal or not.

Table 3 Normality testing by One-Sample Kormogolov-Smirnov Test One-Sample Kolmogorov-Smirnov Test

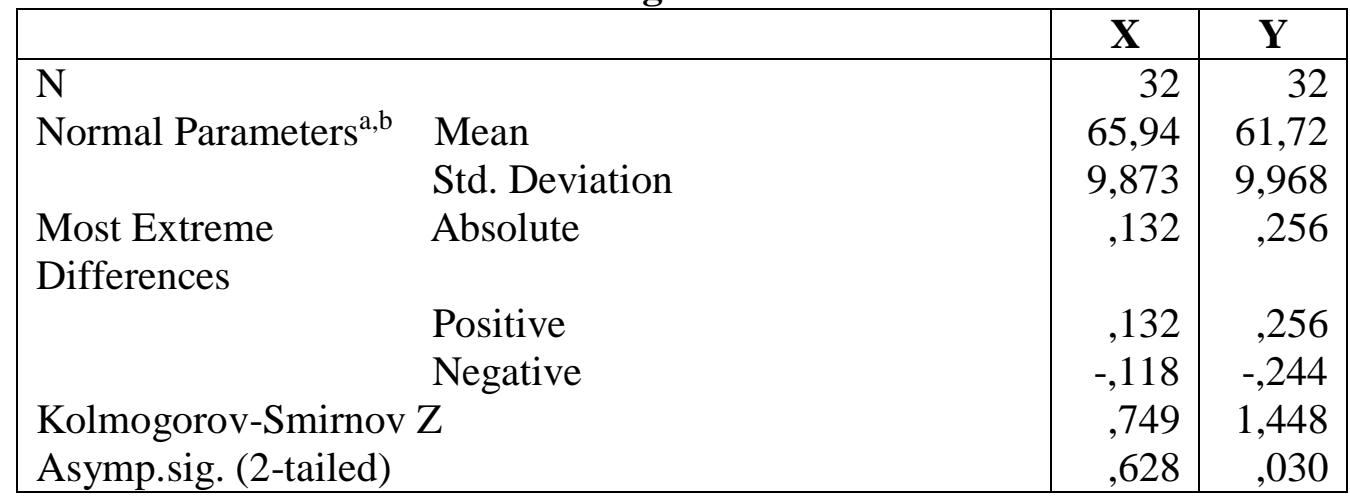

The table 1 showed that the result of the distribution of the data was not normal, because based on the significance Y (0.030) was smaller than 0.05 . It means that the data was not normal.

\section{b. The correlation between students vocabulary mastery and their reading comprehension}

From the data above, the writer got the result of each variable. That is the result of the correlation between students' vocabulary mastery and reading comprehension. 
Table 5 Analysis result of spearman rho correlation

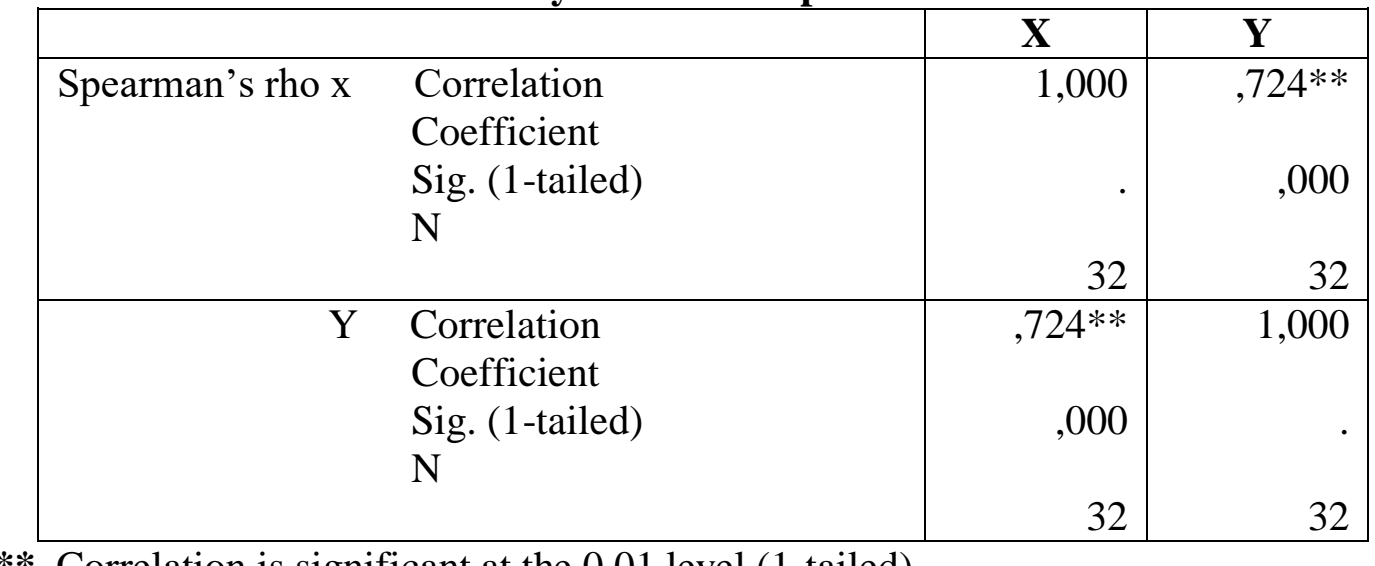

**. Correlation is significant at the 0.01 level (1-tailed)

The table above showed that the correlation coefficient equalled $r_{s}=.724$, which indicated there was positive correlation between two variables.

\section{Discussion}

As described in previous chapter, the aims of this research is to analyse the students', achievement of vocabulary mastery and reading comprehension, and correlation between students' vocabulary mastery and their reading comprehension.

Regarding to the eresult above, the correlation coefficient equalled $r_{s}=.724$, which indicated there was positive correlation between two variables. From the $r_{s}$ number (.724), the writer concluded that there was strong correlation between two variables (see the interpretation correlation on tablea 3.2). The number of .724 resided between $r=.50$ to .1.o. It means that the strength was large correlation. Based on the data, vocabulary and reading was significant because Sig. 1-tailed (0.000) was smaller than 0.05. It means that, if the students mastered in vocabulary, so they would be mastered in reading comprehension.

The result of this research has been answered that there is a correlation between students' vocabulary mastery and their reading comprehension. It could be considered as a strong correlation since the result was included into strong category (Arikunto,2003). In addition to the ability of students' vocabulary mastery, the stratefy and background knowledge of the text help students comprehend the text.

In improving students reading comprehension, teacher should teach vocabulary to their students since vocabulary has strong relationship with reading comprehension. Having a lot of vocabulary makes the students understand the text easily. Although strategy of reading and experience of students help them in comprehend a text, but vocabulary mastery is more important in helping the students to comprehend the text. According to nation and Newton (1997) vocabulary is knowledge of words and word meanings. Actually vocabulary is more complex, vocabulary mastery is not only knowing the words and its meaning, but also knowing about how the words sound and how the words are used in context.

\section{CONCLUSION}

This study focuses on the correlation between students' vocabulary mastery and their reading comprehension. 
Referring to the result and discussion, it was found out that there is a strong correlation between students' vocabulary mastery and their reading comprehension. Although the scores of vocabulary and reading test are different but the correlation is strong.

There are many factors that help students to comprehend the reading materials. The result show that are students' background knowledge and experience. Those factors may help students comprehend reading materials. When they found unknown word they could guess the meaning of unknown word by referring them to the text.

\section{REFERENCES}

Beck, I.L, et al. (1982). Effect of Long-Term Vocabulary Instruction on Lexical Access and Reading Comprehension. Journal of Educational Psychology, 74, 506-521.

Hiebert, E.H., \& Kamil, M.L. (2005). Teaching and Learning Vocabulary; Bringing Research to Practice. London: Lawrence Erlbaum Associates, Inc.

Creswell, J. W. (2012). Educational Research: Planning, Conducting and Evaluating Quantitative and Qualitative Research. Boston: Pearson Education.

Moreillon, J. (2007). Collaborative Strategies for Teaching Reading Comprehwnsion: Maximizing your impact. USA: American Library Assiciaation.

Sadoski, M. (2004). Conceptual Foundations of Teaching Reading. London: The Guildford Press.

Nuttall, C. (1982). Teaching Reading Skill in a Foreign Language. London: The Neumann Educational ltd.

Spears D. (2013). Improving Reading Skill: Seventh Edition. New York: The McGraw-Hill Com[anise Inc.

Thornbury, S. (2002). How to Teach Vocabulary. Harlow: Longman Pearson Education Ltd.

Creswell, J. W. (2012). Educational Research: Planning, Conducting and Evaluating Quantitative and Qualitative Research. Boston: Pearson Education.

Kaswan, \& Suprijadi, D. (2013). Research in English education. Bandung: Putra Praktisi.

Hinton, P.R., et al. (2004) SPSS Explained. USA: Routledge.

Pallant, J. (2007). SPSS: Survival Manual. England: Open University Press. 